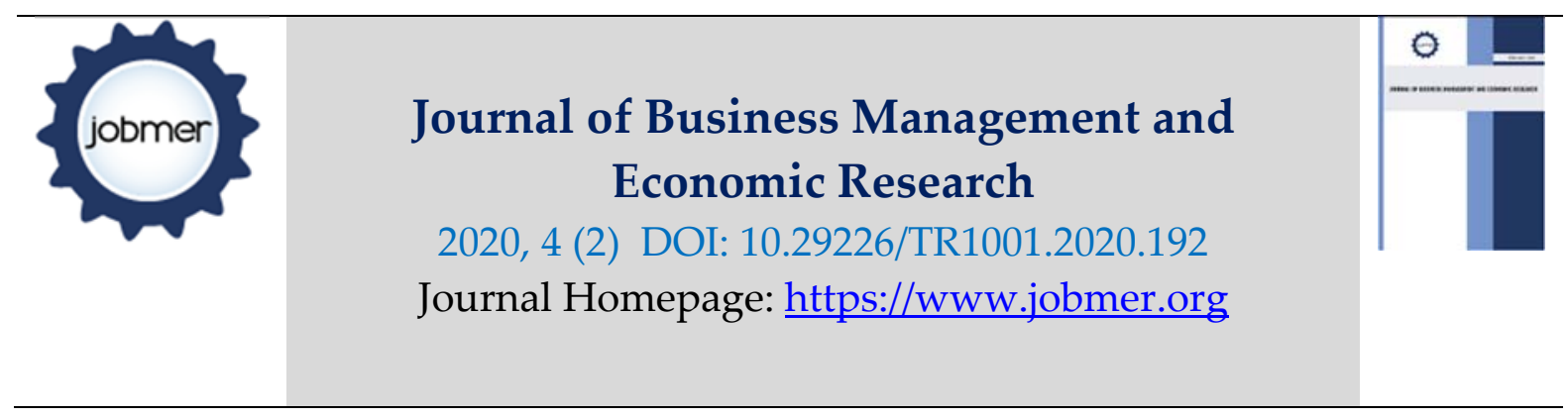

\title{
Analysis of Challenges and Opportunities for Vietnamese SMEs in the Globalization
}

\author{
Vuong Khanh Tuan \\ Malaysia University of Science and Technology, Malaysia \\ vuong.tuan@phd.must.edu.my
}

\begin{abstract}
SMEs play a vital role in Vietnam's economy and society development. However, when wanting to operate within the global market, there are many advantages and disadvantages not only for the larger corporations as well as Vietnamese SMEs. When conducting business in Vietnam there is high competition for the Vietnamese SMEs with other international corporations. Vietnamese SMEs have to change/ innovate their thinking towards the business and management capacity to catch up and maintain their competitiveness in the global market. Therefore, this empirical study will analysis of the challenges and opportunities to Vietnamese SMEs. The methods to conduct this empirical study are based on the secondary data to analysis and give some key solutions to support the Vietnamese SMEs to survive and develop sustainably in the international integration stage.
\end{abstract}

Keywords: SMEs, global integration, competitive advantage, opportunities, challenges, Vietnam.

JEL Classification: M1, M10, M16

\section{Suggested Citation:}

Tuan, V. K. (2020). Analysis of Challenges and Opportunities for Vietnamese SMEs in the Globalization. Journal of Business Management and Economic Research (JOBMER), Vol: 4, Issue: 2, 169185.

\section{Introduction}

Nowadays, the business environment is changing rapidly. These changes affect the large corporations and SMEs not only in Vietnam but also in other countries. Globalization and its processes within the markets will give large and small firms many challenges (Ocloo et al., 2014). Additionally, when Vietnam promotes itself into the International Market, Vietnam's market is then viewed by International 
Journal of Business Management and Economic Research (JOBMER), Vol.4, Issue.2, pp.169-185

firms as a lucrative market, thus creating a more competitive market for the local SME'S here in Vietnam. In the stage of international integration, there is tremendous competition among the local enterprises with multinational corporations. SMEs have to develop and initiate the correct strategies to embrace the changing circumstances in the world market place (Ocloo et al., 2014). Therefore, Vietnamese enterprises should change and innovate to adapt to the new era.

According to Mwika et al., (2018), it is evidenced that in most emerging markets that SMEs have been the key drivers of the overall economic growth structure of the country with both negative and positive outcomes. In the era of economic globalization, SMEs are presented as an engine of sustainable economic advancement in both the developed and developing countries (Prasanna et al., 2019). In recent years, Vietnamese SMEs have played a vital role in socio-economic development, making significant contributions to GDP, creating jobs and stabilizing the economy (Phung, 2019). According to Phung (2019), on average, from 2012 to 2017, the number of SMEs increased by $8.8 \%$, higher than the average growth of large enterprises of $5.4 \%$. Therefore, the role of SMEs is crucial to support the Vietnamese economy and make a stronger society. The development of SMEs is a vital role to maintain their competitive advantage to compete with international corporations (Nguyen, 2019).

On the other hand, many studies have highlighted many challenges facing SMEs in a globalized context (Abu et al., 2006; Aris, 2007; Samad, 2007; Subhan et al., 2013; Mwika et al., 2018). The challenges that SMEs face such as; lack of finances, low productivity, heavy regulatory burden and the limitation of human capital development (Tran, 2019). In the emerging market, the limitation of managerial capabilities and the issues in accessing quality management and technology are the challenges facing SMEs (Wafa, et al., 2005; Mwika et al., 2018; Nguyen, 2019). Like other emerging and developing countries, the SME's within Vietnam also have some limitations in the stage of international integration. According to Nguyen, (2019), SME's need to focus on the importance of their management competence to ensure their success, if not the SME will fail. Vietnamese SMEs have further limitations, such as; low capital, low level of management, use of manual laborer, outdated production technology lines and or lack of competitiveness (Tran, 2019).

Additionally, the strength and quality of cash flow management within the setting of the budget process in Vietnamese SMEs are limited and sufficient to support the SME's success (Nguyen, 2019). Besides, According to Phung, (2019), Compared with other countries in the region and the world, Vietnamese SMEs have many limitations in terms of advantages within the global market due to overall scale, level 
Journal of Business Management and Economic Research (JOBMER), Vol.4, Issue.2, pp.169-185

of contribution and cannot realize their full potential. Hence, to survive and develop in the new era, Vietnamese SMEs should change their overall approach and implementation to management thus improving their ability to manage and for the business to compete against their rivals in the global market. Therefore, due to the above issues, this article will analyze the challenges and opportunities thus giving the solutions to support the Vietnamese SMEs to adapt, change and innovate in the period of international integration.

\section{Literature Review}

\subsection{Globalization}

There are many alternate views on the concept of globalization by different people and in different contexts. "The concept of globalization now cuts across the entire spectrum of academic thinking as it is being defined differently by various scholars" (Ocloo et al., 2014). Globalization is the concept used to describe the changes in society and the world economy, created by the growing linkages and exchanges among nations, organizations or individuals in the corner such as cultural, economic, etc on a global scale.

"Globalization describes the process in which national and regional economies have become integrated and inter-dependent through global network trade, immigration, communication and transportation" (Samad, 2007). Globalization is a social change, a growing interconnection between societies and its elements due to cross-culturalization; the explosion of traffic and communication technologies has contributed to international cultural and economic exchanges. This term can be used in different social, cultural, commercial and economic contexts. Economic globalization is recognized as an opportunity for both developed and developing countries to enhance their economic prosperity by improving their participation in global trade (World Trade Report, 2016).

According to Mwika et al., (2018), globalization has brought about some advantages and disadvantages. For example, globalization can support the laborers to share skills in the working environment, or globalization reduces monopoly profits and globalization can allow enterprises to do business internationally, etc. On the other hand, where there is more competitiveness when globalization happens in the market. Globalization has led to vulnerability if the small enterprises where they are lacking in technology and management capacity, etc. Therefore, there are many advantages and 
disadvantages for the large corporations and SMEs face in the globalization; they must adopt change to adapt to survive and develop.

Globalization, international economic integration, and trade liberalization have been a prominent trend in the contemporary world economy and also in Vietnam. In line with that trend, from 1986 up to now, Vietnam has carried out the renovation and accelerated international economic integration. In the case of Vietnam, there are many Word Organizations and agreements that Vietnam has participated in the below table.

Table 1. Vietnam's global and regional economic integration events by year

\begin{tabular}{|l|l|l|}
\hline No & Event & Year \\
\hline 1 & ASEAN Free Trade Agreement (AFTA & 1996 \\
\hline 2 & ASEAN- China (ACFTA) & 2002 \\
\hline 3 & ASEAN- Korea (AKTIG) & 2006 \\
\hline 4 & Vietnam's participation into WTO & 2007 \\
\hline 5 & ASEAN- Japan & 2008 \\
\hline 6 & ASEAN- Australia- New Zealand & 2009 \\
\hline 7 & ASEAN- India & 2009 \\
\hline 8 & Vietnam- Japan (VJEPA) & 2009 \\
\hline 9 & Vietnam- Chile (VCFTA) & 2014 \\
\hline 10 & Vietnam Korea (VKFTA) & 2015 \\
\hline 11 & Vietnam- Eurasian Economic Union (EAEU) & 2015 \\
\hline 12 & TPP & 2015 \\
\hline
\end{tabular}

Source: Ngo (2016).

Vietnam consistently implements the external policy of independence, peace, cooperation, and development; Foreign policy is open, multilateral, diversifies international relations, proactively and actively integrates into the international economy, and expands international cooperation in many fields. Evidenced in table 1 above, Vietnam is a friend and reliable partner of countries in the international community, actively participating in the international and regional cooperation process. Therefore, from the above analysis, there are many challenges and opportunities for Vietnamese enterprises as well as SMEs have to change to reduce the disadvantages and to get the opportunities in the global market.

\subsection{The definition of SMEs}

According to Mwika et al., (2018), there is no formal definition of SMEs, the definition depends on the country. Each country has different definitions of SMEs. Vietnamese SMEs are classified on the basis of 
the total workforce and total capital of the firm. The definition on SME which is specified in Decree 56/2009/ND-CP: Small and medium-sized enterprises are business establishments that have registered their business according to law and are divided into three levels: very small, small, and medium according to the sizes of their total capital investment (equivalent to the total assets identified in an enterprise's accounting balance sheet) or the average annual number of employees. Table 1 below shows the definition of SMEs in Vietnam by the Vietnamese Government's Decree No.56/2009/ND-CP.

Table 2. The definition of SMEs in Vietnam

\begin{tabular}{|c|c|c|c|c|c|}
\hline \multirow[t]{2}{*}{ Sector } & \multirow{2}{*}{\begin{tabular}{|l|}
$\begin{array}{l}\text { Micro } \\
\text { enterprises }\end{array}$ \\
Number \\
laborers
\end{tabular}} & \multicolumn{2}{|c|}{ Small-sized enterprises } & \multicolumn{2}{|c|}{ Medium-sized enterprises } \\
\hline & & of Total capital & $\begin{array}{l}\text { Number } \\
\text { laborers }\end{array}$ & Total capital & $\begin{array}{l}\text { Number } \\
\text { laborers }\end{array}$ \\
\hline $\begin{array}{l}\text { I. Agriculture, } \\
\text { forestry and } \\
\text { fishery }\end{array}$ & $\begin{array}{l}10 \text { persons or } \\
\text { fewer }\end{array}$ & $\left|\begin{array}{ll}\text { VND } & 20 \\
\text { billion } & \text { or } \\
\text { less } & \end{array}\right|$ & \begin{tabular}{|l} 
Between \\
over 10 \\
persons and \\
200 persons
\end{tabular} & $\begin{array}{lr}\text { Between } & \text { over } \\
\text { VND } & 20 \\
\text { billion } & \text { and } \\
\text { VND } & 100 \\
\text { billion } & \\
\end{array}$ & $\begin{array}{l}\text { Between over } \\
200 \text { persons and } \\
300 \text { persons }\end{array}$ \\
\hline $\begin{array}{l}\text { II. Industry and } \\
\text { construction }\end{array}$ & $\begin{array}{l}10 \text { persons or } \\
\text { fewer }\end{array}$ & $\left|\begin{array}{ll}\text { VND } & 20 \\
\text { billion } & \text { or } \\
\text { less } & \end{array}\right|$ & $\begin{array}{l}\text { Between } \\
\text { over } 10 \\
\text { persons and } \\
200 \text { persons }\end{array}$ & $\begin{array}{lr}\text { Between } & \text { over } \\
\text { VND } & 20 \\
\text { billion } & \text { and } \\
\text { VND } & 100 \\
\text { billion } & \\
\end{array}$ & $\begin{array}{l}\text { Between over } \\
200 \text { persons and } \\
300 \text { persons }\end{array}$ \\
\hline $\begin{array}{l}\text { III. Trade and } \\
\text { service }\end{array}$ & $\begin{array}{l}10 \text { persons or } \\
\text { fewer }\end{array}$ & $\begin{array}{ll}\text { VND } & 10 \\
\text { billion } & \text { or } \\
\text { less } & \end{array}$ & $\begin{array}{l}\text { Between } \\
\text { over } 10 \\
\text { persons and } \\
50 \text { persons }\end{array}$ & $\begin{array}{lr}\text { Between } & \text { over } \\
\text { VND } & 10 \\
\text { billion } & \text { and } \\
\text { VND } & 50 \\
\text { billion } & \\
\end{array}$ & $\begin{array}{l}\text { Between over } 50 \\
\text { persons and } 100 \\
\text { persons }\end{array}$ \\
\hline
\end{tabular}

Source: Decree No.56/2009/ND-CP.

The purpose of small and medium-sized enterprises' classification is to implement the main guidelines to help develop SMEs; on the other hand, to strengthen the Vietnamese Government to manage and support the development of small and medium enterprises in the country. The classification given by the government demonstrates the importance of the role and position that the SMEs play within the National Economy. 


\subsection{The growth of SMEs}

\subsubsection{Number of SMEs in Vietnam, 2006-2015}

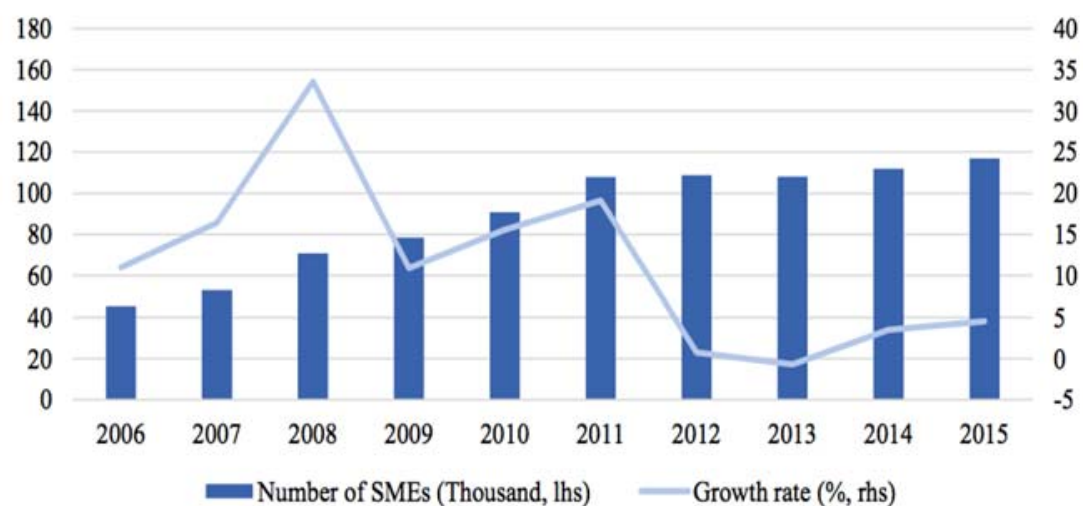

Notes: Micro-enterprises not included.

Figure 1. Number of SMEs in Vietnam, 2006-2015

Source: Pham \& Nguyen, (2017).

In the period of ten years (from 2006 to 2015) the number of SMEs in Vietnam has increased rapidly. This rapid growth generated by the SMEs is a major contributor to economical growth and stronger society in Vietnam.

\subsubsection{Total employment of SMEs in Vietnam, 2006-2015}

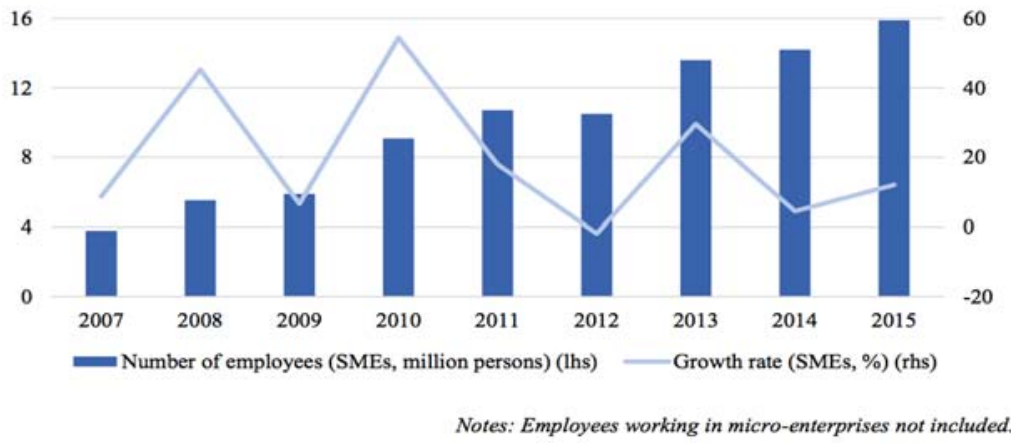

Figure 2. Total employment of SMEs in Vietnam, 2006-2015

Source: Pham \& Nguyen, (2017). 
An increase in the number of employment within SMEs has strengthened. It means that SMEs contributed to providing employment for citizens and increased stability in society.

\subsubsection{Total capital of SMEs in Vietnam, 2006-2015}

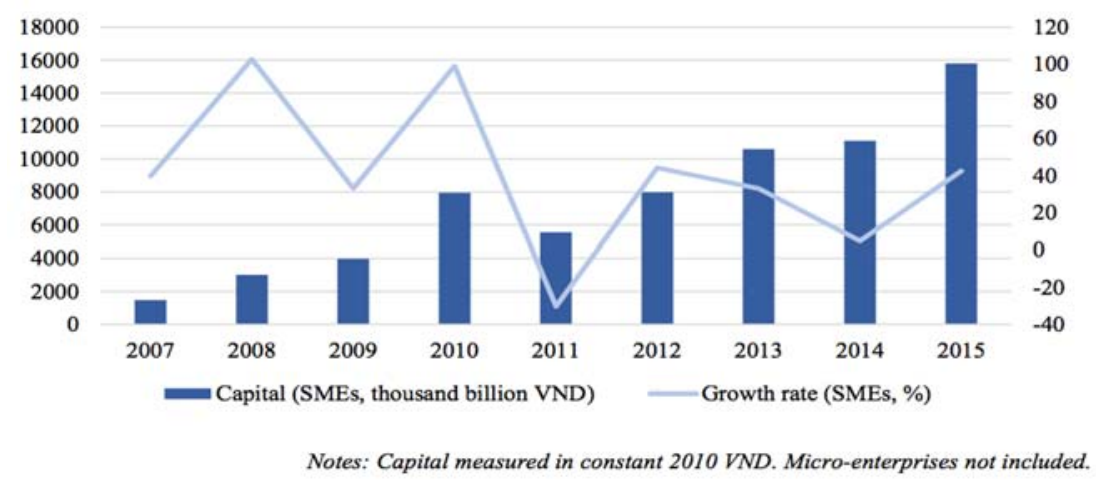

Figure 3. Total capital of SMEs in Vietnam, 2006-2015

Source: Pham and Nguyen, (2017).

There was a strengthened upward trend in the capital for SMEs. Specifically, in 2007, the SMEs' capital was below VND2,000 billion. This figure continued to increase to VND16,000 billion in 2015.

In general, there is a significant increase in the number of SMEs and the employees who worked within SMEs from 2006-2015 and this figure has increased in the current year. The development of SMEs takes a vital role to develop the Vietnamese economy and stronger society.

\subsection{The contribution of SMEs in Vietnam}

Small businesses cannot consider themselves as strict domestic businesses in the current competitive global environment (Sitharam and Hoque, 2016). SMEs are significantly key drivers of economic development in most developing countries (Mazanai \& Fatoki, 2011; Chu, 2015; Mwika et al., 2018; Nguyen, 2019). For enterprises, that want to survive in a globalized and dynamic world, they have to be able to adjust swiftly and effectively to new conditions (Mailu et al., 2018). Thus, in the globalized era, large enterprises and SMEs have to cope with both opportunities and challenges where they must be familiar and ready for the change. The number of SMEs develop significantly in many countries at present. The role of SMEs is very important to support the national economy and support for social 
development such as providing the job for employees. Additionally, in Vietnam, the number of micros/ small and medium-sized - enterprises has increased significantly. The data is shown in the below figure:

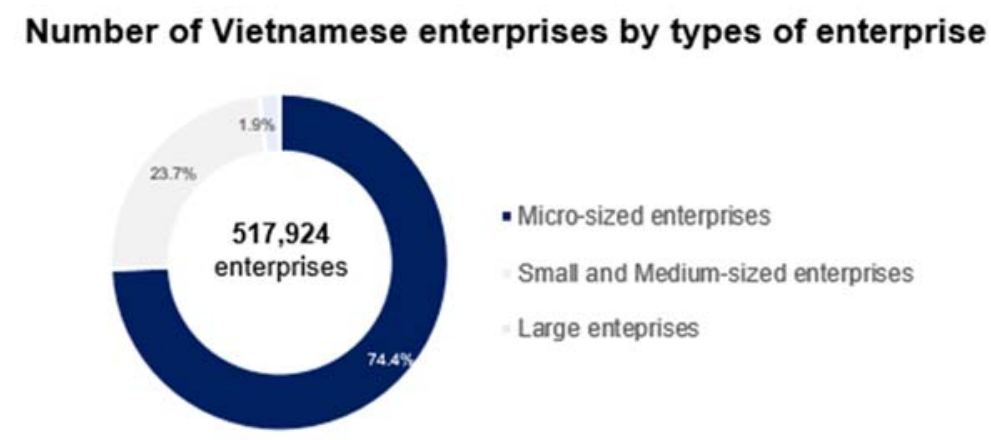

Figure 4. Number of Vietnamese enterprises by types of enterprises.

Source: GSO

According to the results of the Economic Census in 2017 by the General Statistics Office of Vietnam (GSO), The number of Micro-sized enterprises and SMEs in Vietnam accounted for around 98\%. Therefore, the role of Micro-sized enterprises and SMEs is very important to support Vietnamese economics and society.

Table 3. SMEs in Vietnam compared to OECD average

\begin{tabular}{|l|l|l|l|}
\hline \multicolumn{4}{|l|}{ SMEs in Vietnam compared to OECD average } \\
\hline & Vietnam (2018) & $\begin{array}{l}\text { SMEs as \% of } \\
\text { total (Vietnam) }\end{array}$ & $\begin{array}{l}\text { SMEs as of total } \\
\text { (OECD) }\end{array}$ \\
\hline $\begin{array}{l}\text { Registered } \\
\text { companies }\end{array}$ & 517,924 & $98.06 \%$ & $99 \%$ \\
\hline Workforce & $14,081,327$ & $44.48 \%$ & $45 \%$ \\
\hline GDP contribution & $100 \%$ & $40 \%$ & $33 \%$ \\
\hline $\begin{array}{l}\text { Export } \\
\text { contribution }\end{array}$ & $100 \%$ & $30 \%$ & $40 \%$ \\
\hline
\end{tabular}

Source: GSO, VINASME, WTO, OECD

According to the above table, SMEs contribute around $44 \%$ of the workforce and $40 \%$ of GDP for Vietnam while $30 \%$ of the export contribution. The data has revealed, the role of SMEs in Vietnam is essential for economic development and society stable. Therefore, it is crucial to research the field of SMEs to support their management, to adapt and develop in the period where there is high completion among enterprises in the global economy. 


\subsection{SME policy index scores for Viet Nam}

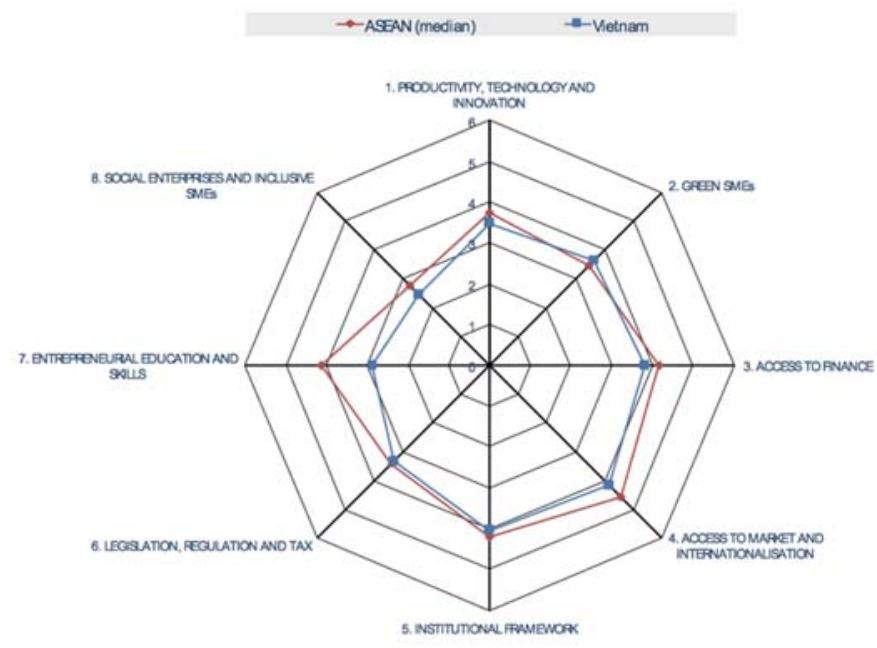

Figure 5. SME policy index scores for Vietnam.

Source: OECD/ERIA (2018)

According to OECD/ERIA (2018), SME policy index scores for Viet Nam, namely: productivity, technology, and innovation; green SMEs; access to finance; access to market and internationalization; institutional framework; legislation, regulation, and tax; entrepreneurial education and skills; social enterprises and inclusive SMEs.

From the statistics of OECD/ERIA (2018), Vietnam has a stronger institutional framework, (Dimensions 5), The country's scores of 4.05 for the institutional framework. Vietnam attains a score with a 3.32 for legislation, regulation and tax reflect (Dimensions 6). Facilitating SME access to finance (Dimension 3), the country's score of around 4. Vietnam access to markets and internationalization (Dimension 4); The country's score of 4.15 for this dimension reflects its mid-stage level of policy development. The evidence shows Vietnam's ability to be successful in these markets. Significant improvement in productivity, innovation, and adoption of new technologies (Dimension 1 and 2); Vietnams score of 3.48 for Dimension 1 places it at a mid-stage of policy development, while its score of 3.63 for Dimension 2 on Green SME places it an early stage of policy development. Stimulating entrepreneurship and human capital development (Dimensions 7 and 8). Vietnam is still to develop a policy framework for the promotion of skills and education's enterprises as well as for inclusive and social SMEs. In comparison with ASEAN's position, Vietnam needs to provide improvement in the following area; 
entrepreneurship and human capital development. This focus will realize Vietnam a better position overall.

\section{The challenge of Vietnamese SMEs at the present}

Along with the trend of globalization, Vietnam is increasingly integrating deeply into the world economy. Along with the opportunities brought about by international economic integration, Vietnamese enterprises in general and SMEs in particular also face many difficulties and challenges (Nguyen, 2019; Tran, 2019). The resources of Vietnamese SMEs such as capital, quality of labor resources, management capacity and technology application, etc are still limited. Since then, the management and operations of many SMEs have not achieved the expected efficiency, making the productivity and competitiveness of Vietnamese enterprises in general still low.

Additionally, according to Chu, (2015); Nguyen, (2019), The role of the SME sector is very crucial in developing the society such as providing more jobs, reducing poverty and a much stronger economy. The SME sector takes a vital role not only to develop the Vietnamese economy but also to provide additional support creating stability society. However, in the international integration stage, Vietnamese SMEs still have some challenges that they need to tackle to survive and adapt to the market. According to Mwika et al., (2018), SMEs are more effective now in the face of globalization which has become more influential within the global trading market. SMEs have benefits from the international integration but they also have many disadvantages as below mentioned:

Firstly, the challenge of Vietnamese SMEs is highly competitive in international markets (Ngo, 2016; Dang and Nguyen, 2017; Nguyen, 2019). According to Tran, (2019), Vietnamese SMEs lack of competitiveness in the global market. Therefore, SMEs should improve their competitive advantages in the market such as they have to innovate their products/services to complete with their rivals in the market; improving their technology and overall restructure within SMEs.

Secondly, Vietnamese SMEs have many limitations in management skills and methods of operating enterprises in the international integration (Chu, 2015; Nguyen (2017); Dang and Nguyen, 2017; Vu et al., 2019; Nguyen, 2019; Tran, 2019). Additionally, according to the Vietnam Institute for Economic and Policy Research, despite SMEs development in past decades, there is nearly 56 percent of SMEs that do not have sufficient knowledge in business and corporate management, financial management, and business law (Nguyen, 2019). So that they can survive in the global market, Vietnamese SMEs should 
improve the management capacity to complete with international corporations (Nguyen, 2019). Therefore, to survive and adapt to the global market, Vietnamese SMEs should change their management process and they need to find out which management factors that support their firm performance to catch up with the trend of the global market.

Thirdly, Vietnamese SME's have a financial limitation within the management of their cash flow incorporated in the overall budget process development and implementation (Chu, 2015; Tran (2015); Vu et al., 2019; Nguyen, 2019;). SMEs faces many challenges in the globalization era including; absence of adequate and timely finances, limited capital as well as access to international market and knowledge (Anand, 2015; Mwika et al., (2018). The limitation in financial resources is one of the major barriers for SMEs in terms of integration (Chu, 2015; Dang and Nguyen, 2017; Nguyen, 2019). Additionally, according to Nguyen, 2019, Vietnamese SMEs need to adopt the world best practices in developing budget process for their enterprises, giving added support to the performance of business and management. Budget setting in SMEs is not linked to reality and it affects the overall business and management (Chu, 2015). If the budget process is not linked to reality or the mistakes come from the budget process, these activities of the business will generate waste to the budget (Doan et al., 2015). Additionally, there is asymmetric information between the management and employees to set up the overall budget for business and management within SMEs. Therefore, to improve the quality of the budget setting, SMEs should improve the overall budget process adapting it for suitability to better planning and implementation of all the activities of the business, management, operation, and manufacturing, etc.

Fourthly, according to Nguyen, (2019), It is evident that SMEs need to improve their skills to enable them to develop and implement the systems and procedures for better business planning and increase their capacity for managerial control. The functions of planning and controlling take a vital role to support the goals and objectives for the SME's development. Therefore, SMEs have a limitation in developing and implementing capacity that should be improved. There are many areas that SMEs need to improve overall to their business planning: market analysis, competitor analysis, developing and implementing a good corporate vision and mission statements to their enterprises" (Chu, 2015, Nguyen, 2019). SMEs are aware of the importance of business planning. However, they have not focused on making a complete business plan in its own right to bring optimal efficiency, but often give sketchy plans due to lack of resources, human resources and time. If SMEs do not have a good business plan, no matter how great their business ideas are, it will be difficult to succeed to any degree. A good 
Journal of Business Management and Economic Research (JOBMER), Vol.4, Issue.2, pp.169-185

business plan not only determines the success of making SME's original business idea a reality but provides continued success for the SMEs. Therefore, to adapt to the highly competitive global market, SMEs should prepare a good business plan to support them to survive and develop.

Fifthly, according to Nguyen, (2019), The limitations that face the SME's management is the lack of financial performance and its management. The core values of the firm are not only the measurement of the financial performance but also the non-financial performance. The financial indicators can only reflect the performance of organizations in the past and do not reflect the firm's future operating conditions (Okoye, et al., 2017). Therefore, Vietnamese SMEs should consider focusing both financial and non-financial indicators on their business, management, operation, and manufacturing, etc.

\section{Opportunities for Vietnamese SMEs}

The first one is the opportunities to access the international market: In the international integration stage, Vietnamese SMEs have a chance to widen their scope to do business (Ngo, 2016; Nguyen, 2019). There are many opportunities for Vietnamese SMEs in expanding into the export market. Vietnam is currently focused on attracting Foreign Direct Investment (FDI) and actively participating in Free Trade Agreements (FTA). This has shown strong commitments on improving the investment environment and protecting intellectual property rights. When large international corporations invest in Vietnam, SMEs have the opportunity to participate in the flow-on benefits in the global value chain. Vietnam now has access to the international market for goods and services in all member countries attracting reduced import tariffs and non-discriminatory service sectors.

Secondly, opportunities to access advanced production technologies (Ngo, 2016). Participating in large markets with investment from bilateral and multilateral trade agreements, SMEs will have the opportunity to innovate systems and technologies to produce products that meet the quality of the markets.

Thirdly, there is an opportunity to improve the quality of the workforce (Ngo, 2016), due to the higher quality and volume requirements of the international market. SMEs should not only consider the improvement of their technology but also they should improve the quality of the workforce to meet the requirement of a higher international standard. Therefore, SMEs should focus on their understanding of the market plus investing in employee training, fostering, developing and implementing strategies for their workforce. Running concurrently with the training and development of SME's human 
resources. They should focus more attention on the upgrading of the employees' development and training within the corporate culture of the SMEs. Human resource is a core factor within the business is vital for the continued development and ongoing success.

The fourth opportunity is access to financial capital from international investment (Ngo, 2016). When Vietnam participates in the global market, there are many chances for SMEs to attract more investment because there is a large pool of investors that come to Vietnam seeking to do business. Therefore, if the SMEs have an attractive business with great opportunities seeking investment, the international investors will seek to support their financing requirements enabling them to widen their scale of business.

\section{Conclusions and Recommendations}

Conclusions: As noted in the analysis above, the SME sector are faced with many challenges but there are also many opportunities available to do business in the global market. To adapt in the international integration, SMEs need to focus on promoting the opportunities and look to reduce the challenges faced. To gain the outcomes from the benefits of the global market, SMEs need to be innovative and adopt the new methods, this will see an improvement in the businesses such as; quality management, leaner operations and higher productivity in manufacturing. SME need to promote the talent within their employees with targeted and concise training, adjust and restructure their overall management capacity and seek current innovative technology to gain a higher market share to equal the fast changing market. Moreover, given the important role and position of the SME sector in the Vietnamese economy, It is necessary to synchronously implement solutions and policies thus encouraging SMEs to develop this internally, in conjunction with assistance from their Government. Government support will create opportunities for SMEs to access the resources and market to develop in the global integration. The Government can offer incentives such as; tax exemption, technology support, legal and taxation incentive advice and providing advice in market opportunities, etc. These supports will allow SMEs to have a better advantage over its rivals and to reduce the many challenges in the global market. Besides that, SMEs need to upgrade their management capacity and innovation in the strategies to get opportunities and reducing risks in the highly competitive market.

Additionally, most of the challenges facing businesses stems internally from the SMEs, due to the lack of appropriate management capacity as well as understanding the methods to exploit and optimize 
existing resources in the enterprises. The process of international economic integration requires SMEs to change business planning, corporate culture, strategy implementation, and managerial control, etc, that will support SMEs to meet its development requirements. To complete in the global market, SMEs should review and adopt a new vision, mission, management structure and process to adapt to the new market. The changes needed by the SMEs will improve their business, its management, operation, and manufacturing to catch up and maintain the level of commitment with the progressive international corporations around the world.

Recommendations: Noted within the analysis above; there are many changes that SMEs should do to catch up with the change of the global market. The role of SMEs and the Vietnamese government are crucial to support SME's development in the new era. There are many solutions to support SMEs development as noted:

Firstly, Human Resources are the decisive factor for the success or failure of a business, so for long-term and sustainable development, investing in human resources in SMEs is critical in the success. Therefore, SMEs should have a decisive plan to acquire the required talent with clear and defined levels of training. The combined talent developed and generated when the foreign enterprises enter the Vietnamese market with a progressive approach and professional attitude toward talent management with a good remuneration structure. This combined leads to a good overall team to do business and develop longterm sustainably.

Secondly, build a system of financial institutions to serve the capital needs SMEs, enabling SMEs to access capital sources with low-interest finance through Government policies and decrees. The Government should promote financing through the avenue of accelerated interest rate reduction.

Thirdly, it is necessary to raise awareness to the SME community on the critical importance of information technology, the application of the information in production and business activities. This is a vital step to keep up the demand for information technology application development in socioeconomic development and international economic integration of the whole country.

Fourthly, business planning provides the underpinning basis of the business. Development and the implementation of each critical step by the business management from its initiation and continuing through the business life-cycle. The plan incorporates; know what your business is and can provide and what are its goals, implement strategies financial, management, sales/ marketing, manufacturing, etc. With good planning, the SMEs will attain a good/ better outcome in the Global market. 
Fifthly, SMEs should improve the managerial controlling process. In an ever-changing environment, the implementation of the control system and its function is mandatory for the management. Implementing the control function, managers will get information on the performance of employees, capture changes in the reality compared to the plan and thereby make appropriate adjustments. On the other hand, the implementation of the control function provides an effective avenue to; motivate the employees, the implementation of the proposed plans and the setting of targets and goals. The management function of the control activity is to monitor, measure, review and rectify its implemented path in order to ensure the achievement of the defined goals. Managerial control will take a key place within the management process of SMEs. Managerial control is the key factor to be utilized by Vietnamese SMEs in discovering the errors and making adjustments to suit. On the other hand, the improvement of control will be performed better and reduce errors that may arise within SMEs

Sixthly, Corporate culture plays a crucial role in the development of both the large corporations and SMEs alike. Corporate culture is all the core values created during the development and existence of any SME. The culture of the company has a makeup of core values, concepts, practices and traditions ingrained within the enterprises activities and govern the sentiments, thoughts and behaviors of every SME member pursuant to its implementation and goals. As with culture in general, corporate culture building for SME has specific characteristics. First of all, corporate culture is the product of employees who implementing and attaining the needs for sustainable values. It establishes a system of values which are accepted, shared, promoted and creates the most desirable culture for the SMEs. Corporate culture will promote the difference between SMEs and is evidenced through employee retention and external jealousy from rival SME and their employees. Therefore, there are a need to build a great corporate culture and identity within SMEs, this provides a good environment, increases the commitment from both management and employees, with a flow on creating substantial values over time gaining a higher share in the global market.

Seventhly, it is difficult for a small and medium-sized enterprise to penetrate into the international markets, secure contracts and gain a dominant share of the market. Businesses need to network within the available sectors and link-up through similar players with the industries. SMEs need to review and reassess the markets, analysis and consider the new competitive landscape in Vietnam and Internationally, prepare in readiness for the transition into the new era. Develop a strategy to improve their competitiveness, identify the core values and to select products/services and their target markets. 
Journal of Business Management and Economic Research (JOBMER), Vol.4, Issue.2, pp.169-185

Finally, it is the SMEs in Vietnam that need to be proactive and innovative in the strategy of implementation when entering the global market. They should improve overall core elements such as governance of management capacity, productivity, quality management, promote competitiveness of their products and services within the market. Additionally, standardize and create lean production of the business to meet the requirements and criteria of international markets. Furthermore, promote and enhance innovation, research and development in applied technology for manufacturing. When adopting these core principals and applying the noted systems, technologies and providing core training to all levels of employees the SME's will gain greater sustainable success into the future. Flowing on from this adoption is the added promotion of the national spirit, a united focus in building a greater Vietnamese brand for products and services within the international market.

\section{References}

Abu Bakar, J., Mad, C., \& Abdul Latif, R. (2006). Liberalization and globalization: a case of Naza and a lesson to SME. Proceedings of Persidangan Kebangsaan IKS 2006.

Aris, N. M. (2007). SMEs: Building blocks for economic growth. Department of National Statistics, Malaysia.

Chu, H. M. (2015). Factors affecting to budget process in small and medium-sized enterprises (SMEs) in Ho Chi Minh City-Vietnam. Master's thesis. Ho Chi Minh City University of Technology.

Dang, T. P H., \& Nguyen, V. K. (2017). Vietnamese small and medium-sized enterprises: legal and economic issues of development at modern stage. Economics and management of enterprises, 165(5-6), 128-132.

Dang, T. P. H (2016). Legislative policies in support of Vietnam SMEs. KTRA's International Conference, Globalization of SMEs and Capacity Building in the TPP Era, 537-556, Retrieved from: http://www.kiep.go.kr/cmm/fms/FileDown.do;jsessionid=Mnlvr Q7Asd4zUm8m0ljubwtISZx719ZloqH9aydDqYpLOsIUg5sJZMO8mo0UCdRa.KIEPWEB_N EW_servlet_engine4?atchFileId=FILE_000000000012613 \&fileSn=1\&bbsId=seminarData (Accessed on 22, December 2019).

Doan, N. Q, Dao, T. T., and Le, D. T. (2015). Accounting management. University of Economics, Ho Chi Minh City. Economics Publication of HCMC.

Mwika, D., Banda, A., Chembe, C., \& Kunda, D. (2018). The Impact of Globalization on SMEs in Emerging Economies: A Case Study of Zambia. International Journal of Business and Social Science, 9(3), 59-68. doi:10.30845/ijbss.v9n3p6

Mazanai, M., \& Fatoki, O. (2011). The effectiveness of Business Development Services Providers (BDS) in improving access to debt finance by start-up SMEs in South Africa. International Journal of Economics and Finance, 3(4), 208.

Ngo, T. T. H. (2016). Vietnamese small and medium sized enterprises (SMEs) in the period of global economic integration: Opportunities and challenges. Retrieved from: 
http://www.tapchigiaothong.vn/vietnamese-small-and-medium-sized-enterprises-smes-inthe-period-of-global-economic-integration-opportunities-and-challenges-d28210.html (Accessed on 20, December 2019).

Nguyen, M. C. (2019). Expanding the global role for Vietnam's SMEs. Vietnam investment review. Retrieved from: https://www.vir.com.vn/expanding-the-global-role-for-vietnams-smes71069.html (Accessed on 08, January 2020)

Nguyen, T. T. T. (2019). Analysis of the Management Process to Enhance SMEs Performance in Ho Chi Minh City. International Journal of New Technology and Research, 5(12), 9-15

Ocloo, C. E., Akaba, S., \& Worwui-Brown, D. K. (2014). Globalization and Competitiveness: Challenges of Small and Medium Enterprises (SMEs) in Accra, Ghana. International Journal of Business and Social Science, 5(4), 287-296.

OECD/ERIA. (2018). SME Policy Index: ASEAN 2018: Boosting Competitiveness and Inclusive Growth. OECD Publishing, Paris/Economic Research Institute for ASEAN and East Asia, Jakarta. https://doi.org/10.1787/9789264305328-en

Pham, T. T. T., \& Nguyen, D. T. (2017). Development characteristics of SME sector in Vietnam: Evidence from the Vietnam enterprise census 2006-2015. Working Paper WP-18, Viet Nam Institute for Economic and Policy Research, Hanoi.

Phung, T. D. (2019). Supporting Vietnamese in their small and medium-sized enterprises in their current developments. Retrieved from: http://tapchitaichinh.vn/tai-chinh-kinh-doanh/ho-tro-doanhnghiep-nho-va-vua-viet-nam-phat-trien-trong-giai-doan-hien-nay-314736.html (Accessed on 28, December 2019).

Samad, N. (2007). Positioning Malaysian SMEs in the global. Proceedings of Persidangan Kebangsaan IKS.

Subhan, Q. A., Mehmood, M. R., \& Sattar, A. (2013). Innovation in Small and Medium Enterprises (SME's) and its impact on Economic Development in Pakistan. Paper presented at the Paper was presented in 6th International Business and Social Sciences Research Conference.

Suárez, C. A. (2016). Best Management Practices: SMEs' Organizational Performance Management Based on Internal Controls in Mexico. Journal of International Business and Economics, 4(2), 4158.

Sitharam, S., \& Hoque, M. (2016). Factors affecting the performance of small and medium enterprises in KwaZulu-Natal, South Africa. Problems and Perspectives in Management, 14(2-2), 277-288.

Tran, N. T. (2019). Improvement of Vietnamese small and medium enterprises competitiveness in international integration. Political theory. Retrieved from: http://lyluanchinhtri.vn/home/en/index.php/practice/item/642-improvement-of-vietnamesesmall-and-medium-enterprises-competitiveness-in-international-integration.html (Accessed on 09, January 2020).

Wafa, S., Noordin, R., \& Kim-Man, M. (2005). Strategy and performance of small and medium-size enterprises in Malaysia. Paper presented at the Proceedings of the International Conference in Economics and Finance (ICEF).

World Trade Report (2016). World Trade Organization: Geneva, Switzerland. 